\title{
Morbidity-mortality and performance evaluation of Brahman calves from in vitro embryo production
}

\author{
Andreza Pimenta-Oliveira', José P Oliveira-Filho ${ }^{1 *},{\text { Adriano } \text { Dias }^{2} \text { and Roberto C Gonçalves }}^{1}$
}

Background: The use of bovine in vitro embryo production (IVP) increases the reproductive potential of genetically superior cows, enabling a larger scale of embryo production when compared with other biotechnologies. However, deleterious effects such as abnormal fetal growth, longer gestation period, increased birth weight, abortion, preterm birth and higher rates of neonatal mortality have been attributed to IVP. The aim of this study was to compare the influence of in vitro embryo production and artificial insemination (Al) on gestation length, complications with birth, birth weight, method of feeding colostrum, passive transfer of immunity, morbiditymortality, and performance in Brahman calves.

Results: Whilst gestation length and birth weight were significantly increased in IVP-derived calves, no difference in weaning weight was observed between groups. The passive transfer of immunity (PT), was assessed in IVP ( $n=$ $80)$ and $\mathrm{Al}(\mathrm{n}=20)$ groups 24 hours after birth by determination of gamma-glutamyl transferase (GGT) and gammaglobulin activity as well as by quantification of the concentration of total protein in serum. No differences in passive transfer or incidences of dystocia and diseases at weaning were observed between groups. Birth weight, method of feeding colostrum and dystocia were not correlated with PT in either group.

Conclusions: In this study, in vitro embryo production did not affect the health status, development, or passive transfer of immunity in Brahman calves.

\section{Background}

The use of bovine in vitro embryo production (IVP) has increased in Brazil over the past several years. This procedure allows for embryos to be obtained from genetically superior cows that are no longer able to produce offspring by conventional techniques or procedures. IVP increases the reproductive potential of the cows when compared with other biotechnologies such as artificial insemination (AI) [1]. However, though IVP promotes faster genetic improvement [1], it has also been associated with a number of adverse effects such as higher embryo mortality rates, abnormal fetal growth, heavier offspring, longer gestation, abortion, preterm birth, increased genetic abnormalities and high rates of neonatal mortality $[2,3]$.

\footnotetext{
* Correspondence: zefilho@fmvz.unesp.br

'School of Veterinary Medicine and Animal Science - Univ Estadual Paulista, UNESP, Botucatu, Sao Paulo, Brazil

Full list of author information is available at the end of the article
}

Dystocia in newborn calves can cause asphyxia and so delay onset of natural suckling, negatively affecting the passive transfer of colostral immunoglobulins [4]. Dystocia is also associated strongly with increased mortality, morbidity and with a detrimental impact on health and development from birth to weaning [5]. The failure of passive transfer causes hypogammaglobulinemia which increases the susceptibility to neonatal disease, low growth performance, and high mortality [6].

The aim of this study was to compare the influence of in vitro embryo production and artificial insemination (AI) on gestation length, complications with birth, birth weight, method of feeding colostrum, passive transfer of immunity, morbidity-mortality, and performance in Brahman calves. 


\section{Methods}

Farm

The study was conducted in a purebred Brahman farm (Bos taurus indicus) (S: 230.'34.7" and W: 48 ${ }^{\circ} 27^{\prime} 12.2^{\prime \prime}$ ) located in Pardinho county in Sao Paulo, Brazil. The property comprises an area of 260 hectares, most part covered with Brachiaria sp. grass. The animals were raised under a semi-intensive system and were under permanent veterinary care.

\section{Animals}

Regardless of gender, 100 Brahman calves were selected based on their method of production and divided into two groups during one calving season (i.e., six months). Eighty calves were from IVP offspring (IVP group) and 20 were produced by artificial insemination (AI group). At birth, umbilical disinfection was performed with 5\% iodine. Individual animals were identified by tattoo and cow tag earrings and dewormed with $200 \mu \mathrm{g} / \mathrm{kg}$ of body weight $(\mathrm{BW})$ of doramectin subcutaneously. The calves were kept under natural grazing conditions with mineral salt licks and water ad libitum. Supplemental creep feeding consisted of Cynodon dactylon ground hay (1\% $\mathrm{BW})$, corn silage $(3 \% \mathrm{BW})$, and $1 \% \mathrm{BW}$ of a commercial concentrate (crude protein 19\%, crude fat 3\%, crude fiber $12 \%$, mineral matter $11 \%$, calcium $1.5 \%$, phosphorus $0.6 \%$ ).

All of the calves ingested colostrum during the 6 hours from birth, irrespective if by natural suckling, bottle feeding or nasogastric tube feeding. Calves were kept with their mothers until weaning (i.e., 210 days). Over this period, clinical assessment of calves was performed and any disease treated.

The cows used in our experiment were negative for brucellosis and tuberculosis and vaccinated against infectious bovine rhinotracheitis, bovine virus diarrhea, campylobacteriosis, leptospirosis and clostridiosis. Multiparous Brangus and Simbrasil cows were used as recipients for IVP embryos. Multiparous Brahman cows were artificially inseminated and the offspring used for the AI group. The semen used for both in vitro embryo production and artificial insemination techniques was obtained from two Brahman sires of an independently owned semen company. Follicular aspiration as well as in vitro embryo production and transfer were performed by a technician from a biotechnology company. Artificial insemination was achieved by a single technician.

One month before birth, dams were placed in maternity pens with mineral salt licks and water ad libitum and supplemented with corn silage (3\% BW) and $1 \%$ BW of a commercial concentrate (crude protein $20 \%$, crude fat $2.5 \%$, crude fiber $8 \%$, mineral matter $11 \%$, calcium $2 \%$, phosphorus $0.5 \%$ ).

\section{In vitro embryo production}

Cumulus-oocyte complexes (COCs) were obtained by ovum pick-up (OPU) from Brahman donors. Each donor was subjected to one OPU session using a SSD500 ultrasound scanner $\left(\right.$ Aloka $^{\circledR}$, Tokyo, Japan) with a 5 $\mathrm{MHz}$ sector transducer (Aloka ${ }^{\circledR}$, Tokyo, Japan) attached to the transvaginal guide (Cook ${ }^{\circledR}$ Medical, Bloomington, USA). Ovum pick-up was performed using an 18G needle under vacuum $(500 \mathrm{~mm} \mathrm{Hg}$ ). The cumulus oocytecomplexes were collected into phosphate buffered saline medium (Cultilab ${ }^{\circledR}$, Campinas, Brazil) with $1 \%$ fetal calf serum (FCS) and $5 \mathrm{IU}$ of heparin/mL. Prior to in vitro maturation COCs were assessed morphologically, and only those that had a cumulus morphology quality I and II [7] were selected.

All selected COC's were in vitro matured in $30 \times 10$ mm dishes $\left(\right.$ Corning $^{\circledR}$, Lowell, USA) with $100 \mu \mathrm{L}$ drops of modified TCM-199 medium with 10\% FCS (Cultilab ${ }^{\circledR}$, Campinas, Brazil). This medium was supplemented with $5 \mu \mathrm{g} / \mathrm{mL}$ of FSH (Folltropin- $\mathrm{V}^{\circledR}$, Bioniche Animal Health, Belleville, Canada) and $50 \mu \mathrm{g} / \mathrm{mL}$ of LH (Lutropin- $\mathrm{V}^{\circledR}$, Bioniche Animal Health, Belleville, Canada), 1 $\mu \mathrm{g} / \mathrm{mL}$ of porcine estradiol, $100 \mu \mathrm{g} / \mathrm{mL}$ of epidermal growth factor human (EGFh), $6.25 \mu \mathrm{g} / \mathrm{mL}$ of insulin, 22 $\mu \mathrm{g} / \mathrm{mL}$ of pyruvate, and gentamicin. For in vitro maturation the COCs were incubated for $24 \mathrm{~h}$ at $39^{\circ} \mathrm{C}$ under humidified $5 \% \mathrm{CO}_{2}$ in air.

After maturation, oocytes were transferred to $30 \times 10$ mm dishes $\left(\right.$ Corning $^{\circledR}$, Lowell, USA) containing $100 \mu \mathrm{L}$ Tyrode's albumin-lactate-pyruvate medium with $22 \mu \mathrm{g}$ of pyruvate $/ \mathrm{mL}, 6 \mathrm{mg}$ of BSA $/ \mathrm{mL}, 10 \mu \mathrm{g}$ of heparin $/ \mathrm{mL}$, $20 \mu \mathrm{M}$ of penicillamine $/ \mathrm{mL}, 10 \mu \mathrm{M}$ of hypotaurine $/ \mathrm{mL}$, and $2 \mu \mathrm{M}$ of epinephrine $/ \mathrm{mL}$. Oocytes were inseminated with $2 \times 10^{6}$ sperm $/ \mathrm{mL}$ and maintained at $39^{\circ} \mathrm{C}$ with $5 \%$ $\mathrm{CO}_{2}$ in saturated humidity for 18 to $24 \mathrm{~h}$. Following insemination, putative zygotes were removed by successive pipetting. The in vitro culture was performed in 30 $\times 15 \mathrm{~mm}$ dishes with $100 \mu \mathrm{L}$ Synthetic Oviduct Fluid medium [8] containing $4 \mathrm{mg} / \mathrm{mL}$ of bovine serum albumin BSA and 2\% FCS. Embryos were incubated under humidified $5 \% \mathrm{CO}_{2}, 5 \% \mathrm{O}_{2}$ and $90 \% \mathrm{~N}_{2}$ at $39^{\circ} \mathrm{C}$. All embryos were removed from culture on day seven of development and transferred to synchronized recipients.

\section{Sample collection}

Data were obtained regarding pregnancy technique (IVP or AI), gestation length, type of delivery (normal parturition or dystocia, use of obstetric chains or cesarean section), direct or indirect (i.e., bottle or oral-esophagic tube) colostrum feeding, and weight at birth, 30, 60, 90, 120 and 210 days after delivery. The animals were checked daily until weaning and more thoroughly when there was evidence of clinical alteration. Data on the 
presence and frequency of diseases were individually recorded.

Blood samples from the calves were collected via jugular puncture using a $21 \mathrm{G}$ needle and serum tubes, 24 hours after birth. Samples were centrifuged and serum stored in plastic tubes at $-20^{\circ} \mathrm{C}$ until tests. The protocol was approved by the Committee of Ethics and Animal Welfare of the Univ Estadual Paulista (UNESP), School of Veterinary Medicine and Animal Science, Brazil.

\section{Diagnosis of failure of passive transfer (FPT)}

Diagnosis of FPT was assessed by determination of gamma-glutamyl transferase (GGT) activity in serum, according to the kinetic-colorimetric method previously describe [9], with a commercial kit (Katal ${ }^{\circledR}$, Belo Horizonte, Brazil) and a SB-190 automatic analyzer $\left(\mathrm{Celm}^{\mathbb{B}}\right.$, Barueri, Brazil) set at $405 \mathrm{~nm}$ length wave. Separation of the gammaglobulin protein fraction from serum was performed by electrophoresis in agarose gel $\left(\mathrm{Celm}^{\circledR}\right.$, Barueri, Brazil) stained with amido black $(0.1 \%)$ in $5 \%$ acetic acid [10]. Samples were read using a SE-250 scanner $\left(\right.$ Celm $^{\circledR}$, Barueri, Brazil). Total protein was quantified by direct biuret method [11] using the automatic analyzer and a commercial kit $\left(\mathrm{Katal}^{\circledR}\right.$, Belo Horizonte, Brazil). FPT was considered to have occurred when the calf had at least one of the following values: total protein $(<5.0 \mathrm{~g} / \mathrm{dL})$, gammaglobulin $(<1.0 \mathrm{~g} / \mathrm{dL})$ and/or serum GGT $(<100 \mathrm{IU} / \mathrm{L})$ [12].

\section{Statistical analysis}

Data were analyzed by Chi-square or Fisher's exact test when variables were categorical. Due to the non-normal distribution of continuous variables, comparison between AI and IVP groups was performed using the nonparametric Mann Whitney U test. All correlations were conducted using the Spearman RHO test. The significant level of analysis was established at $5 \%$.

\section{Results and discussion}

Gestation length of IVP offspring was significantly longer than AI offspring ( $p<0.001)$, with means of 294 \pm 6.6 days and $287 \pm 6.7$ days, respectively (Table 1 ). Previous studies have also reported significant increases (nine days) in the gestation length of IVP calves when compared with AI calves [13]. However, this difference has not always been observed [14]. No difference in gestation length was observed between IVP and AI Gyr calves (Bos indicus) [15], suggesting that the effect of the IVP on the gestation length is less perceptible in zebu breeds, which intrinsically have longer gestation periods.

As in other studies [13-15], birth weight in our study was significantly increased $(p=0.038)$ in IVP when compared to AI calves, with mean values of $41 \pm 5.8 \mathrm{~kg}$ and $38 \pm 4.7 \mathrm{~kg}$, respectively (Table 1 ). However, although the relationship between increased birth weight and longer gestation period has previously been described [16], no significant association between these variables was found in our experiment $(0.166, \mathrm{p}=0.142$ for IVP and 0.374, $\mathrm{p}=0.104$ for AI). Moreover, significant differences in gestation length were not found between IVP and AI groups. It is important to mention that though the birth weight can be influenced by the characteristics of the sire [15], the male effect was not considered in our study due to the proportional use of semen from the very same two sires in both groups. In order, to increase the efficiency of IVP [17] we supplemented the bovine embryo culture medium with FCS. Long-term effects of medium composition on fetal development have been observed such as increased birth weight after culture in media containing serum $[14,18]$. However, other authors [19] did not observe influence in birth weight among IVP calves regardless the use of embryo culture with or without FCS.

Males were heavier than females at birth in a previous work [20]. In our study males were heavier at birth in both groups. Males $(43.5 \pm 4 \mathrm{~kg})$ and females $(39 \pm 6.2$ $\mathrm{kg}$ ) from the IVP group were heavier than the males (41 $\pm 2.9 \mathrm{~kg})$ and females $(36 \pm 4.1 \mathrm{~kg})$ from the AI group. These results agree with other studies [13-15], which compared body weight between IVP and AI offspring. However, breed of the mother could be a factor

Table 1 Gestation length, delivery, feeding method, and weight from birth to weaning of the Brahman calves

\begin{tabular}{|c|c|c|c|c|c|c|c|c|c|c|c|}
\hline \multirow[t]{2}{*}{ Group } & \multirow[t]{2}{*}{ Gestation length $^{1}$} & \multicolumn{2}{|c|}{ Delivery } & \multicolumn{2}{|c|}{$\begin{array}{l}\text { Method of feeding } \\
\text { colostrum }\end{array}$} & \multirow[b]{2}{*}{ Birth weight ${ }^{2}$} & \multirow[b]{2}{*}{ W30 3} & \multirow[b]{2}{*}{ W60 } & \multirow[b]{2}{*}{ W90 } & \multirow[b]{2}{*}{ W120 } & \multirow[b]{2}{*}{ W210 } \\
\hline & & Eutocic & Dystocic & Direct & Indirect & & & & & & \\
\hline IVP & $294 \pm 6.6^{a_{*}}$ & $\begin{array}{c}80 \% \\
(64 / 80)\end{array}$ & $\begin{array}{c}20 \% \\
(16 / 80)\end{array}$ & $\begin{array}{c}92.5 \% \\
(74 / 80)\end{array}$ & $\begin{array}{c}7.5 \% \\
(6 / 80)\end{array}$ & $41 \pm 5.8^{a}$ & $75 \pm 13.5^{a}$ & $100 \pm 14.4$ & $130 \pm 18.5$ & $160 \pm 21.4$ & $221 \pm 27.4$ \\
\hline Al & $287 \pm 6.7^{b}$ & $\begin{array}{c}95 \% \\
(19 / 20)\end{array}$ & $\begin{array}{c}5 \% \\
(1 / 20)\end{array}$ & $\begin{array}{c}95.0 \% \\
(19 / 20)\end{array}$ & $\begin{array}{c}5.0 \% \\
(1 / 20)\end{array}$ & $38 \pm 4.7^{b}$ & $67 \pm 10.8^{b}$ & $94 \pm 18.1$ & $124 \pm 20.2$ & $157 \pm 23.4$ & $215 \pm 32.9$ \\
\hline
\end{tabular}

${ }^{1}$ Mean gestation length (days)

${ }^{2}$ Mean birth weight $(\mathrm{kg})$

${ }^{3}$ Mean weight (kg) at 30 (W30), 60 (W60), 90 (W90), 120 (W120), and 210 (W210) days after delivery

*Different letters $(a, b)$ indicate significant difference $(P<0.05)$ between IVP and Al groups 
affecting offspring birth weight. It is known that Brahman cows limit fetal growth during the last third of gestation when compared with Charolais cows [21]. This restriction seems to be a consequence of decreased weight of placentomas and reduced uterine blood flow in Brahman cows [22]. In contrast to the results from these authors $[21,22]$ the breed of the recipient cow was not incorporated as a factor influencing birth weight [23]. These authors attribute the increased birth weight of IVP offspring to factors such as the use of multiparous recipients, sex of the calf, handling conditions and intrinsic characteristics of the IVP technique e.g., use of frozen embryos. Thus, as all cows in our study were multiparous and submitted to the same procedures under the same handling conditions, we strongly believe that the breed of the recipient cows in both IVP (mixed zebu) and AI (pure zebu) groups did not influence the birth weight of the calves. Moreover, the use of different breeds as embryo receptors was not considered in the assessment of birth weight, gestation length, and development of calves produced either for IVP or AI in previous studies [24].

IVP individuals may have abnormal placental and/or fetal development, causing the so called large offspring syndrome, characterized by excessively large calves at birth, high perinatal mortality, hydrallantois and increased number of abortion [18]. Calves with large offspring syndrome were not present in our study. Even so, $6.3 \%(5 / 80)$ of the IVP-derived calves displayed a mean birth weight $30 \%$ heavier than the mean AI calf weight. The same pattern was found at day 30 i.e., IVP calves were significantly heavier than AI calves $(\mathrm{p}=0.017$ ) (Table 1). However there were no significant differences in mean weight between groups at 60, 90, 120 and 210 days of age (i.e., weaning) which demonstrates the effect of feeding on offspring development (Table 1).

Weight and size at birth, associated with the specific characteristics of the recipients and embryos, as well as with the number of births, were the main factors causing dystocia in Nelore recipients [25]. Other authors reported more dystocia in IVP than AI calves $(62 \%$ and $10 \%$, respectively) [14]. However, the increased birth weight of IVP-derived offspring $(n=26)$ did not provoke delivery problems when compared with AI calves $(\mathrm{n}=32)$ [15]. In the same study, only one case of dystocia was present in a $35 \mathrm{~kg}$ IVP-derived calf, whilst the heaviest animal was a $37 \mathrm{~kg}$ IVP female [15]. It is therefore, possible that the low rate of dystocia has been a consequence of the relatively lower birth weight of IVP Gyr calves compared with other breeds, e.g., Nelore [15]. Dystocia was only observed in in vitro and in vivo derived calves weighing more than $40 \mathrm{~kg}$ [25].

Despite observing dystocia in $20 \%(16 / 80)$ of IVP births, i.e., one cesarean section and 15 births using obstetric chains; and in 5\% (1/20) of the AI calves, no significant differences were identified between groups ( $p$ $=0.096$ ) (Table 1). Fourteen of the 16 IVP calves with dystocia had birth weight above the mean value for this group ranging between 41 and $56 \mathrm{~kg}$. Therefore, whilst birth weight contributes to the occurrence of dystocia, other factors must also be evaluated at mating and in the selection of recipient cows [25].

Dystocia may result in trauma to the newborn affecting its disposition to nurse. Although normal neonates may show mild acidosis, the intense and prolonged delivery contractions and the inability to breathe provoke an acid-base imbalance in calves with dystocia [26]. Long and laborious delivery, e.g., more than 4 hours, can cause fetal hypoxia, tongue edema, cerebral edema [4], and decreased physical activity leading to a longer period from parturition until the calf stands and nurses colostrum by itself [27]. In fact, this entire clinical picture may diminish or completely cease colostrum absorption [28]. In our study, six calves from the IVP group (bottle $n=4$, esophageal tube $n=2$ ) and one from the AI group (esophageal tube $n=1$ ) were forcedfed colostrum. No significant differences were found between groups regarding the method of feeding colostrum ( $p>0.05$ ) (Table 1). Three of the seven animals (two IVP and one AI calf) that were fed colostrum through non-natural methods suffered dystocia. Still, association between dystocia and non-natural suckling of colostrum was not observed $(\mathrm{p}=0.110)$.

Since maternal immunoglobulin transfer through the placenta does not occur in cattle, the absorption of colostral antibodies is critical to promote the passive immunity during neonatal life [29]. In order to improve passive transfer, colostrum was given either directly or indirectly during the first 6 hours post-delivery in this study.

At least one of the three analyzed variables supposes to be below the normal limits for FPT diagnosis, i.e., total protein $(<5.0 \mathrm{~g} / \mathrm{dL})$, gammaglobulin $(<1.0 \mathrm{~g} / \mathrm{dL})$ and/or serum GGT $(<100 \mathrm{IU} / \mathrm{L})$. Failure of passive transfer was detected in $10 \%$ of the IVP offspring (8/80) and $20 \%$ of the AI offspring (4/20) without significant difference between groups. Only one AI-derived calf had lower GGT (22.3 IU/L), total protein $(4.7 \mathrm{~g} / \mathrm{dL})$ and gammaglobulin $(0.7 \mathrm{~g} / \mathrm{dL})$. Nevertheless, this animal did not experience disease and had a weaning weight of 208 $\mathrm{kg}$, very close to the mean weight of the group.

Though passive transfer is essential for calf survival, several other factors may influence life and performance of the individual $[6,30,31]$. As in our study, Bos taurus IVP-derived calves absorb large amounts of colostral immunoglobulins in order to acquire adequate passive immunity [32,33]. In agreement with our study, Jacobsen et al. also reported no significant differences in IgG 
concentration among IVP and AI offspring [33]. The authors concluded that the low viability of IVP calves is probably unrelated to the ability and/or efficiency of the calf to obtain passive immunity through colostrum [33].

The birth weight, method of feeding colostrum and dystocia were not related with FPT in any of the groups within the current study. Some studies have shown correlations between the increase in FPT and dystocia [34,35]; however, only one of the IVP animals with dystocia (1/16) in the present study suffered FPT (gamaglobulin $=0.37 \mathrm{~g} / \mathrm{dL}$ ). Thereby, the low occurrence of FPT in calves with dystocia in our study agree with other authors, who reported no significant differences in serum immunoglobulins among normal and distocic calves [36], as well as no significant differences in serum total protein and IgG after normal or assisted delivery [37]. However, longer delivery (irrespective if normal or assisted) led to low serum levels of IgG, probably because the longer period until nurse and therefore less colostrum ingested [37].

In general, the low occurrence of FPT in both groups in this study was probably associated with the immediate and comprehensive assistance provided at delivery, thus minimizing the risk of fetal hypoxia and increasing the rate of feeding with colostrum during the first 6 hours after birth. Therefore, the FPT seems to be more related to fail in ingestion of colostrum by the calf rather than to a defective absorption of macromolecules through the intestinal epithelium [37].

At least one disease was present in 40\% (32/80) and $50 \%(10 / 20)$ of the IVP and AI groups respectively ( $\mathrm{p}=$ 0.42) (Table 2). Diarrhea had the highest prevalence i.e., $26(32.5 \%)$ of the IVP calves and seven (35\%) of the AI calves, with no statistical difference between groups ( $\mathrm{p}=$ 0.83) (Table 2). Several authors points out the diarrheic syndrome as one of the most important diseases in neonate calves in Brazil [23,38,39] and other countries [40]. As previously observed [36], most cases of diarrhea were between the 4th and 6th week from birth.

Several risk factors are related to the occurrence of diarrhea, such as excessive exposure to ammonia in closed or airless environments [41] and exposure to enteropathogens [36]. Feeding management, (i.e., nurse [39], milk substitute feeding [41,42], early use of silage in calves' diet [41]) or any other factor interfering in the passive transfer [41] are critical for the outbreak of diarrhea.

We did not observe association between diarrhea and FPT ( $\mathrm{p}=0.757)$. As previously described [12] it is fearful to claim that a neonate is less susceptible to suffer a specific infectious disease based exclusively on the concentration of serum immunoglobulins or indirect parameters. Therefore, other factors related to the quality of the acquired immunity, such as load of pathogens and ingestion of pathogen-specific immunoglobulins, probably justify the mild occurrence of diarrhea in both groups. On the other hand, three IVP calves $(3 / 80$, $3.8 \%$ ) died (Table 2) due to diarrhea and concomitant diseases i.e., omphalitis and bovine babesiosis and anaplasmosis (tick fever). One AI calf also died due to pneumonia $(1 / 20,5 \%)$ (Table 2$)$. No significant differences between the two groups were found for mortality. The three IVP animals which died presented FPT and a significant association between FPT and mortality was observed in this group $(\mathrm{p}=0.025)$. The adequate colostrum feeding [42], permanent veterinary care, and good environmental and nutritional conditions, probably played a role in the low mortality rate, as diarrhea, umbilical diseases e.g., omphalitis, omphalophlebitis, umbilical myasis, and persistent urachus, are very common in calves [12,25,38]. Recently, researchers compared IVP and AI techniques, regarding the occurrence of umbilical diseases and observed significant correlation between persistent urachus and IVP [43]. The use of 5\% iodine solution for 5 days and subcutaneous doramectin is considered a good practice to prevent umbilical disease in beef cattle [38]. No significant difference was identified regarding umbilical disease between groups ( $\mathrm{p}$ $=0.42$ ) (Table 2). The increased number of umbilical disease observed in the IVP group $(n=9)$ compared with the AI group $(n=1)$ may be caused by congenital anomalies or failure of umbilical cord retraction [43]. In our study, omphalitis and persistent urachus were the second most evident diseases in the IVP group $(9 / 80)$, but no association between these abnormalities and FPT was found. Other diseases were also diagnosed in the IVP group as follows: bovine babesiosis and anaplasmosis $(4 / 80)$, corneal ulcer (4/80), and dermatophilosis (1/ $80)$. In the AI group, bronchopneumonia $(2 / 20)$, and bovine babesiosis/anaplasmosis (1/20) were detected.

Table 2 Diseases and death frequencies of the Brahman calves derived from IVP and AI

\begin{tabular}{ccccccccc}
\hline Group & Diseases & Diarrhea & UD $^{1}$ & Tick fever & Corneal ulcer & Dermatophilosis & BCP $^{2}$ & Death $^{2}$ \\
\hline IVP & $40 \%(32 / 80)$ & $32.5 \%(26 / 80)$ & $11.3 \%(9 / 80)$ & $5 \%(4 / 80)$ & $5 \%(4 / 80)$ & $1.2 \%(1 / 80)$ & $-{ }^{\mathrm{a} *}$ & $3.8 \%(3 / 80)$ \\
Al & $50 \%(10 / 20)$ & $35 \%(7 / 20)$ & $5 \%(1 / 20)$ & $5 \%(1 / 20)$ & - & - & $10 \% \%^{\mathrm{b}}(2 / 20)$ & $5 \%(1 / 20)$ \\
\hline
\end{tabular}

${ }^{1}$ Umbilical diseases

${ }^{2}$ Bronchopneumonia

*Different letters $(a, b)$ indicate significant difference $(P<0.05)$ between IVP and Al groups 
Statistical difference was observed regarding the presence of bronchopneumonia $(\mathrm{p}=0.038)(\mathrm{AI}>\mathrm{IVP}$ group) which affected $10 \%$ of the calves of the AI group (Table 2).

In Brazil, livestock production is characterized by large-scale extensive operations under grazing conditions mainly at north and central west of the country. Although the main reproductive strategies are artificial insemination and natural matting, the use of IVP increases each year in animals of high genetic value. With the objective of diminishing the influence of environmental factors, our experiment was performed through a single farm during one calving season. Moreover, this property actually represents an elite livestock Brazilian farm using IVP as the main biotechnology for reproduction and the number of animals used in this experiment accurately reflects the characteristics of the livestock segment in this country. Other authors $[15,24]$ obtained similar results than those in our study regarding gestation length, birth weight and calf development using a slightly lower number of animals. Thus, we emphasize that under these conditions the results from our experiment are reliable and did not suffered the influence of size of the groups.

\section{Conclusions}

Based on our results we can conclude that gestation period and birth weight were higher for the IVP offspring. However, weaning weight was similar between groups. The occurrence of dystocia, assistance for colostrum feeding, FPT and disease in calves were similar from birth to weaning in both groups. Birth weight, method of feeding colostrum and dystocia were not associated with FPT. Under these conditions, we can say that IVP technique did not have influence on health status and performance of Brahman calves or interfered with acquisition of passive immunity.

\section{Acknowledgements}

This study was supported by grants from Fundação de Amparo à Pesquisa do Estado de São Paulo - FAPESP (09/08152-9). The authors thank Kevin Sinclair, PhD, DSc and Adam Watkins, PhD University of Nottingham for their assistance in editing this manuscript. We also thank Mr. Wilson Roberto Rodrigues - W2R owner (farm studied) and president of Brahman Breeders Association of Brazil.

\section{Author details}

${ }^{1}$ School of Veterinary Medicine and Animal Science - Univ Estadual Paulista, UNESP, Botucatu, Sao Paulo, Brazil. ${ }^{2}$ School of Medicine - Univ Estadual Paulista, UNESP, Botucatu, Sao Paulo, Brazil.

\section{Authors' contributions}

APO and JPOF performed the clinical examination, laboratorial analysis, reviewed the literature and prepared the manuscript. AD performed the statistical analysis and prepared the manuscript. RCG reviewed the literature and prepared the manuscript. All authors read and approved the final manuscript.

\section{Authors' information}

APO, JPOF and RCG are from School of Veterinary Medicine and Animal Science - Univ Estadual Paulista, UNESP, Botucatu, Sao Paulo, Brazil. AD is from School of Medicine of the UNESP, Botucatu, Sao Paulo, Brazil.

\section{Competing interests}

The authors declare that they have no competing interests.

Received: 6 April 2011 Accepted: 4 December 2011 Published: 4 December 2011

\section{References}

1. Garcia JM, Avelino KB, Vantini R: Estado da arte da fertilização in Vitro em bovinos. In Annals of the First International Symposium on Animal Reproduction Applied: 14-16 October 2004; Londrina. Edited by: Pietro S. Baruselli and Marcelo Seneda: Faculdade de Medicina Veterinária e Zootecnia, Universidade de São Paulo; 2004:223-230.

2. Numabe T, Oikawa T, Kikuchi T, Horiuchi T: Birth weight and birth rate of heavy calves conceived by transfer of in vitro or in vivo produced embryos. Anim Reprod Sci 2000, 64:13-20.

3. Prestes NC: In vitro production of bovine embryos an obstetric overview of problems and challenges. Acta Scient Vet 2005, 33:119-124.

4. Perino $L$, Wittum TE: Effects of various risk factors on plasma protein and serum immunoglobulin concentrations of calves at postpartum hours 10 and 24. Am J Vet Res 1995, 56:1144-1148.

5. Lombard JE, Garry FB, Tomlinson SM, Garber LP: Impacts of dystocia on health and survival of dairy calves. J Dairy Sci 2007, 90:1751-1760.

6. Feitosa FLF, Birgel EH, Ciarlini PC, Mendes LCN, Perri SHV: Morbidity and mortality of neonate calves related to immunity transfer by colostrum. Continuous Educ J CRMV-SP 2001, 4:9-15.

7. De Loos F, Van Vliet C, Van Maurik P, Kruip TA: Morphology of immature bovine oocytes. Gamete Res 1989, 24:197-204.

8. Holm P, Booth PJ, Schmidt MH, Greve T, Callesen H: High bovine blastocyst development in a static in vitro production system using SOFaa medium supplemented with sodium citrate and myo-inositol with or without serum-proteins. Theriogenology 1999, 52:683-700.

9. Szasz G: A kinetic photometric method for serum gamaglutammyl transpeptidase in calves. Clin Chem 1969, 15:124-135.

10. Naoum PC: Electrophoresis: technical and diagnostics Sao Paulo: Livraria Santos; 1999.

11. Tietz NW: Fundamentals of Clinical Chemistry Toronto: W.B. Saunders; 1970.

12. Feitosa FLF, Camargo DG, Yanaka R, Mendes LCN, Peiró JR, Bovino F, Lisboa JAN, Perri SHV, Gasparelli ERF: Index of failure of passive transfer (FPT) in Holstein and Nelore calves at 24 and 48 hours of life: suggestion of total protein, gamma globulin, immunoglobulin $\mathrm{G}$ and gamma glutamyl transferase serum activity values for diagnosis of FPT. Pesa Vet Bras 2010, 30:696-704.

13. Yang BS, Im GS, Park SJ: Characteristics of Korean native, Hanwoo, calves produced by transfer of in vitro produced embryos. Anim Reprod Sci 2001, 67:153-158.

14. Behboodi E, Anderson GB, BonDurant RH, Cargill SL, Kreuscher BR, Medrano JF, Murray JD: Birth of large calves that developed from in vitro-derived bovine embryos. Theriogenology 1995, 44:227-232.

15. Camargo LSA, Freitas C, As WF, Ferreira AM, Serapiao RV, Viana JHM: Gestation length, birth weight and offspring gender ratio of in vitroproduced Gyr (Bos indicus) cattle embryos. Anim Reprod Sci 2010, 120:10-15

16. Horta AEM: Large calf syndrome associated to the transfer of in vitro produced embryos. Revta Port Zootec 1993, 1:27-41.

17. Leivas FG, Brum DS, Fialho SS, Saliba WP, Alvim MTT, Bernardi ML, Rubin MIB, Silva CAM: Fetal calf serum enhances in vitro production of Bos taurus indicus embryos. Theriogenology 2011, 75:429-433.

18. Farin CE, Farin PW, Blodin P, Crosier AE: Fetal development of in vitroproduced embryos: possible association with uterine function. J Anim Sci 2000, 77:1-16.

19. Thompson JG, Allen NW, MCGowan LT, Bell ACS, Lambert MG, Tervit HR: Effect of delayed supplementation of fetal calf serum to culture medium on bovine embryo development in vitro and following transfer. Theriogenology 1998, 49:1239-1249.

20. Johanson JM, Berger PJ: Birth weight as a predictor of calving ease and perinatal mortality in Holstein cattle. J Dairy Sci 2003, 86:3745-3755. 
21. Gardiner R: Cerebral blood flow and oxidative metabolism during hypoxia and asphyxia in the new-born calf and lamb. J Physiol 1980, 305:357-376.

22. Ferrell C: Maternal and fetal influences on uterine and conceptus development in the cow. II, Blood flow and nutrient flux. J Anim Sci 1991, 70:1954-1965.

23. Merton JS, van Wagtendonk-de Leeuw AM, den Dass JHG: Factors affecting birth weight of IVP calves. Theriogenology 1998, 49:293.

24. Rérat $M$, Zbinden $Y$, Saner R, Hammon H, Blum JW: In vitro embryo production: growth performance, feed efficiency, and hematological, metabolic, and endocrine status in calves. J Dairy Sci 2005, 88:2579-2593.

25. Gasparelli ERF, Camargo DG, Yanaka R, Mendes LCN, Peiró JR, Bovino F, Perri SHV, Feitosa FLF: Physical and serum cortisol levels evaluation of Nelore newborn calves born by normal and laborious parturition. Pesa Vet Bras 2009, 29:823-828.

26. Rice LE: Dystocia-related risk factors. Vet Clin North Am: Food Anim Pract 1994, 10:53-68.

27. Dufty JH, Sloss V: Anoxia in the bovine fetus. Aust Vet J 1977, 53:262-267.

28. Feitosa FLF: The importance of passive immunity transfer to the survival of newborn calves. Continuous Educ J CRMV-SP 1999, 2:17-22.

29. Brambell FWR: The transmission of immunity from mother to young and the catabolism of immunoglobulins. Lancet 1966, 2:1087-1093.

30. Guy MA, McFadden TB, Cockrell DC, Besser TE: Regulation of colostrum formation in beef and dairy cows. J Dairy Sci 1994, 77:3002-3007.

31. Tizard IR: Veterinary Immunology: an introduction Philadelphia: W.B. Saunders; 2004.

32. Bailey TL, Whittier WD, Murphy JM, Schurig GG, Riva AL, Swecker WS, Petzer KD, Bass RT, Caudell D, Eyestone W: Serum immunoglobulin type G concentrations in calves produced by IVF and delivered by elective cesarean section. Theriogenology 1998, 50:853-860.

33. Jacobsen H, Sangild PT, Schmidt M, Holn P, Greve T, Callesen H Macromolecule absorption and cortisol secretion in newborn calves derived from in vitro produced embryos. Anim Reprod Sci 2002, 70:1-11.

34. Donovan GA, Badinga L, Collier RJ, Wilcox CJ, Braun RK: Factors influencing passive transfer in dairy calves. J Dairy Sci 1986, 69:754-759.

35. Schmidt M, Greve T, Avery B, Beckers JF, Sulon J, Hansen HB: Pregnancies, calves and calf viability after transfer of in vitro produced bovine embryos. Theriogenology 1995, 46:527-539.

36. Stott GH, Reinhard EJ: Adrenal function and passive immunity in the dystocial calf. J Dairy Sci 1978, 61:1457-1461.

37. Gasparelli ERF, Camargo DG, Yanaka R, Perri SHV, Nogueira GP, Lisboa JAN, Feitosa FLF: Serum levels of total protein, immunoglobulin $G$ and cortisol in Nelore calves, at the birth and at 24 hours old: influence of the type and the duration of the parturition. Ars Vet 2009, 25:120-124.

38. Oliveira Filho JP, Silva DPG, Pacheco MD, Mascarini LM, Ribeiro MG, Alfieri AA, Alfieri AF, Stipp DT, Barros BJP, Borges AS: Diarrhea in Nelore calves: clinical and etiologic study. Pesq Vet Bras 2007, 27:419-424.

39. Botteon RCCM, Botteon PTL, Santos Júnior JCB, Pinna MH, Lóss ZG: Frequency of diarrhea in dairy calves submitted to different breeding conditions in the border of Rio de Janeiro and Minas Gerais states, Brazil. Braz J Vet Anim Sci 2008, 45:153-160.

40. Virtala AMK, Mechor GD, Gröhn YT, Erb HN: Morbidity from nonrespiratory diseases and mortality in dairy heifers during the first three months of life. J Am Vet Med Assoc 1996, 208:2043-2046.

41. Lorino T, Daudin JJ, Robin S, Sanaa M: Factors associated with time to neonatal diarrhoea in French beef calves. Prev Vet Med 2005, 68:91-102.

42. Schumann FJ, Townsend HGG, Naylor JM: Risk factors for mortality from diarrhea in beef calves in Alberta. Can J Vet Res 1990, 54:366-372.

43. Rodrigues CA, Santos PSP, Perri SHV, Teodoro PHM, Anhesini CR, Araújo MA, Filho MNV: Correlation between conception methods, occurrence, and type o treatment of the umbilical diseases in cattle: A retrospective study. Pesq Vet Bras 2010, 30:618-622.

doi:10.1186/1746-6148-7-79

Cite this article as: Pimenta-Oliveira et al:: Morbidity-mortality and performance evaluation of Brahman calves from in vitro embryo production. BMC Veterinary Research 2011 7:79.

\section{Submit your next manuscript to BioMed Central and take full advantage of:}

- Convenient online submission

- Thorough peer review

- No space constraints or color figure charges

- Immediate publication on acceptance

- Inclusion in PubMed, CAS, Scopus and Google Scholar

- Research which is freely available for redistribution

Submit your manuscript at www.biomedcentral.com/submit 